\title{
STUDIES ON THE NATURE OF THE BLOCK TO POLYSPERMY IN RABBIT OVA
}

\author{
K. GONRAD, J. BUCKLEY AND R. STAMBAUGH \\ Division of Reproductive Biology, Department of Obstetrics and Gynecology, \\ University of Pennsylvania School of Medicine, \\ Philadelphia, Pennsylvania 19104, U.S.A.
}

(Received 10th April 1971)

Previously, we reported the isolation and identification of a trypsin-like enzyme from rabbit sperm acrosomes, which effects penetration of the zona pellucida by spermatozoa (Stambaugh \& Buckley, 1968, 1969; Stambaugh, Brackett \& Mastroianni, 1969; Stambaugh, 1971), and we now know that a similar enzyme exists in rhesus monkey, human and sea-urchin spermatozoa (Stambaugh \& Buckley, 1970; Stambaugh, 1971). Since this enzyme has proved to be similar but not identical to pancreatic trypsin, we have given this enzyme the name 'acrozonase' (Stambaugh, 1971).

Earlier observations, indicating that the zona pellucida of the unfertilized ovum is more readily dissolved by proteolytic enzymes than that of the fertilized ovum (Smithberg, 1953; Chang \& Hunt, 1956; Austin, 1961; Gwatkin, 1964), suggested to us that the block to polyspermy may involve the release of acrozonase inhibitors from the cortical granules after fertilization by the first spermatozoon. Thus, further penetration of the zona by spermatozoa would be inhibited or blocked by acrozonase inhibitor. It was the object of the experiments described here to confirm these earlier observations and to ascertain if the acrosomal hyaluronidase facilitates dissolution of the zona.

Ovulation in mature New Zealand white female rabbits was induced by injection with 100 i.u. HGG, and the unfertilized ova were collected from the oviduct $13 \frac{1}{2} \mathrm{hr}$ later by lavage with Eagle's medium. Some rabbits were primed with 150 i.u. PMsg (Gestyl, Organon, Inc., West Orange, New Jersey) intramuscularly $72 \mathrm{hr}$ before HGG. Fertilized ova were collected $13 \frac{1}{2} \mathrm{hr}$ after mating three times and injection with 75 i.u. HGG. The cumulus oophorus was dispersed within 10 to 15 min using 100 units of testicular hyaluronidase in $1.0 \mathrm{ml}$ of Eagle's medium, and the partially denuded ova were then transferred to Eagle's medium containing 50 mequiv/l of bicarbonate ion to remove the corona radiata cells.

Solutions of crystalline pancreatic trypsin were prepared in $0.05 \mathrm{M}$-phosphate containing $0.2 \mathrm{M}$-sucrose, $\mathrm{pH} \mathrm{7.4}$. Trypsin activity was measured using the procedure of Bergmeyer (1963), and the solutions were diluted to the required enzyme concentrations. Crystalline testicular hyaluronidase was added to these solutions whenever required, in a concentration of $1 \mathrm{mg} / \mathrm{ml}$.

The ova were pipetted from the Eagle's medium into these enzyme solutions at zero time, and then immediately transferred, together with a small amount 
of the enzyme solution, to a microscope slide. A coverslip was applied without distortion of the egg and dissolution of the zona was followed by phase contrast microscopy. The times required for dissolution of more than $25 \%$ or an initial distortion of the zona pellucida were taken as arbitrary end points.

The zonae of eighteen unfertilized and fifteen fertilized ova from unprimed rabbits dissolved in an average time of 9.9 and $35.9 \mathrm{~min}$, respectively, using 7.5

\begin{tabular}{|c|c|c|c|c|}
\hline DISSOLUTION OF & $\begin{array}{cc}\text { THE ZON } \\
\text { TRY }\end{array}$ & $\begin{array}{l}\text { A PELLU } \\
\text { SIN/ML }\end{array}$ & DA WITH & $7.5 \mathrm{mU}$ \\
\hline \multirow{2}{*}{$\begin{array}{c}\text { Dissolution } \\
\text { time } \\
\text { (min) }\end{array}$} & \multicolumn{2}{|c|}{ No. of unfertilized ova } & \multicolumn{2}{|c|}{ No. of fertilized ova } \\
\hline & $\begin{array}{l}\text { Primed } \\
\text { rabbits }\end{array}$ & $\begin{array}{c}\text { Unprimed } \\
\text { rabbits }\end{array}$ & $\begin{array}{l}\text { Primed } \\
\text { rabbits }\end{array}$ & $\begin{array}{c}\text { Unprimed } \\
\text { rabbits }\end{array}$ \\
\hline $\begin{array}{l}0 \text { to } 2 \\
2 \text { to } 4 \\
4 \text { to } 6 \\
6 \text { to } 8 \\
8 \text { to } 10 \\
10 \text { to } 15 \\
>15\end{array}$ & $\begin{array}{r}1 \\
28 \\
17 \\
1 \\
1 \\
0 \\
0\end{array}$ & $\begin{array}{l}0 \\
7 \\
4 \\
2 \\
1 \\
1 \\
3\end{array}$ & $\begin{array}{r}0 \\
0 \\
1 \\
1 \\
2 \\
5 \\
11\end{array}$ & $\begin{array}{r}0 \\
1 \\
1 \\
1 \\
1 \\
1 \\
10\end{array}$ \\
\hline Mean time & $4.6 \mathrm{~min}$ & $9.9 \mathrm{~min}$ & $27.6 \mathrm{~min}$ & $35.9 \mathrm{~min}$ \\
\hline Combined means & \multicolumn{2}{|c|}{5.6 min * } & \multicolumn{2}{|c|}{30.9 min $*$} \\
\hline
\end{tabular}

TABLE 2

\begin{tabular}{lllllll} 
DISSOLUTION OF THE & $\begin{array}{l}\text { ZONA PELLUGIDA } \\
\text { TRYPSIN/ML }\end{array}$ & WITH $15 \mathrm{mU}$ \\
\hline
\end{tabular}

\begin{tabular}{c|cc|c}
\hline $\begin{array}{c}\text { Dissolution } \\
\text { time } \\
(\mathrm{min})\end{array}$ & \multicolumn{2}{|c|}{ No. of unfertilized ova } & No. of fertilized ova \\
\hline 0 to 2 & & & \\
2 to 4 & 102 & $(0)$ & 4 \\
4 to 6 & 20 & $(5)$ & 38 \\
6 to 8 & 8 & $(5)$ & 5 \\
8 to 10 & 0 & $(2)$ & 5 \\
10 to 15 & 10 & $(6)$ & 1 \\
$>15$ & 15 & $(8)$ & 0 \\
Mean time & $\underbrace{5 \cdot 2 \text { min }} 8 \cdot 4$ min & $4 \cdot 5^{*}$ \\
Combined means & \multicolumn{2}{|c|}{6.8 min* } & \\
\hline
\end{tabular}

( ) hyaluronidase added.

* Insignificant difference.

$\mathrm{mU}$ trypsin/ml, while those of forty-eight unfertilized and twenty fertilized ova from primed rabbits dissolved in an average time of 4.6 and $27.6 \mathrm{~min}$, respectively, using the same enzyme concentration (Table 1). The average time of zona dissolution for all unfertilized ova was $5.6 \mathrm{~min}$, while the fertilized ova required $30.9 \mathrm{~min}$.

In a second series of experiments (Table 2) using $15 \mathrm{mU}$ trypsin/ml, the zonae of 162 unfertilized ova dissolved in an average of $5.2 \mathrm{~min}$ while the 
zonae of sixty-four fertilized ova dissolved in an average of $4.4 \mathrm{~min}$. When $1.0 \mathrm{mg} / \mathrm{ml}$ of hyaluronidase was added to the trypsin solution, the zonae of thirty-seven unfertilized ova dissolved in an average of $8.5 \mathrm{~min}$. All rabbits in this series were primed.

These results confirm statistically the previous observations of Chang \& Hunt (1956), Smithberg (1953) and Gwatkin (1964), which indicated that the zona pellucida of the fertilized ovum is more resistant to proteolysis than the zona of the unfertilized ovum. However, an excessive amount of proteolytic enzyme $(15.0 \mathrm{mU}$ trypsin/ $/ \mathrm{ml})$ will overcome this inhibition and the difference will no longer be evident. The results would also seem to indicate that hyaluronidase does not facilitate zona dissolution, provided that the cumulus dispersion with hyaluronidase is not masking the effect. The results would seem to indicate that hyaluronidase actually inhibits the dissolution process. This inhibition may be due to some type of non-specific inhibition, or it might be due to denatured acrozonase in the hyaluronidase preparations. That is, hyaluronidase is isolated from testis extracts, and these preparations could contain some denatured acrozonase which might block the substrate sites on the zona.

In summary, the results indicate that the rabbit ovum does have a block to polyspermy, which may consist of the release of protease inhibitors from the cortical granules, but hyaluronidase does not seem to facilitate this dissolution. However, one must recognize that species differences may occur, and other enzymes and enzyme inhibitors may be involved in other species (Allison \& Hartree, 1970).

This work was supported by NIH contract number 70-2161, and Ford Foundation Grant 650-0058B.

\section{REFERENGES}

Aldison, A. C. \& Hartree, E. F. (1970) Lysosomal enzymes in the acrosome and their possible rôle in fertilization. 7. Reprod. Fert. 21, 501.

Austin, C. R. (1961) The mammalian egg, p. 90. Blackwell Scientific Publications, Oxford.

Bergameyer, H. U. (1963) Methods of enzymatic analysis, p. 815. Academic Press, New York.

Chang, M. G. \& Hunt, D. M. (1956) Effects of proteolytic enzymes on the zona pellucida of fertilized and unfertilized mammalian eggs. Expl Cell Res. 11, 497.

Gwatkin, R. B. L. (1964) Effect of enzymes and acidity on the zona pellucida of the mouse egg before and after fertilization. F. Reprod. Fert. 7, 99.

Smithberg, M. (1953) The effect of different proteolytic enzymes on the zona pellucida of mouse ova. Anat. Rec. 117, 554.

Stambaugh, R. (1971) Acrosomal enzymes and fertilization. In: Proc. Wayne State Symp. on the Biology of Fertilization and Implantation. Charles G. Thomas, Springfield, IIl. (in press).

Stambaugh, R., Brackett, B. G. \& Mastroianni, L. (1969) Inhibition of in vitro fertilization of rabbit ova by trypsin inhibitors. Biol. Reprod. 1, 223.

Stambaugh, R. \& Buckiex, J. (1968) Zona pellucida dissolution enzymes of the rabbit sperm head. Science, N.Y. 161, 585.

Stambaugh, R. \& Buckley, J. (1969) Identification and subcellular localization of the enzymes effecting penetration of the zona pellucida by rabbit spermatozoa. F. Reprod. Fert. 19, 423.

Stambaugh, R. \& Buckizy, J. (1970) Comparative studies of the acrosomal enzymes of rabbit, rhesus monkey, and human spermatozoa. Biol. Reprod. 3, 275. 